\title{
Towards the social doctrine of the Orthodox Church: The document 'For the Life of the World' of the Ecumenical Patriarchate (2020)
}

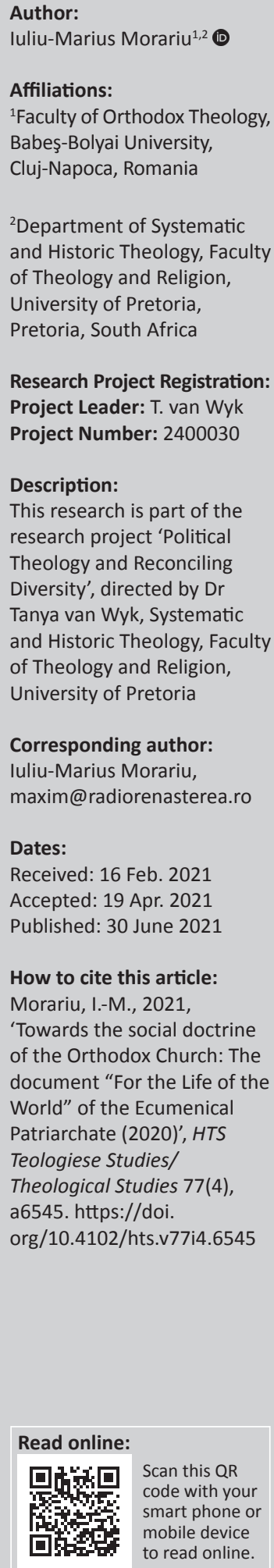

Amongst the recent documents released by the Greek Ecumenical Patriarchate of Constantinople, the one titled 'For the Life of the World', published before the beginning of the COVID-19 pandemic, touches upon an important section of the life of the Orthodox Church, namely, the social one. As a result of the fact that, so far, there is no official document of the aforementioned Church dedicated to this aspect, whilst the Reformed Churches and the Catholic one have already issued similar documents, I consider the existence of such an article, with all its minuses, important. Moreover, it can constitute a bridge and an invitation to dialogue with other Christian traditions or backgrounds. Being aware of this fact, I have decided to analyse this document in this article to emphasise its influence and its elements of novelty and to speak about both its utility and its weaknesses. As a result of the fact that the Ecumenical Patriarch Bartholomew has had an important contribution to its drafting, I will also try to present this aspect and to show how the ecological vision that he has, amongst other aspects, influenced its content.

Contribution: Considering the importance of the recent document 'For the Life of the World of the Ecumenical Patriarchate of Constantinople', I will try to analyse it and to present its social relevance and meaning.

Keywords: The Ecumenical Patriarchate; politics; social ethics; Pan-Orthodox Council of Crete; Patriarch Bartholomew.

\section{Introduction}

Whilst the Catholic Church has a clearly defined social doctrine (Morariu 2020a:33), with a long history, marked by landmarks such as the Rerum Novarum encyclical letter (Pontifical Council for the Justice and Peace 2004:47-56) and the Protestant space, which has a way of acting based on social life, which is applied in many situations, until a few decades ago, in the Orthodox area, the accent was put on the mystical and liturgical life (Ică \& Marani 2002:18; Preda 2010:19) rather than on the social doctrine. This fact is visible both in the ecclesiology of different Protestant Churches and in some of the documents of the World Council of Churches (see, e.g., the World Council of Churches 2019, 2020).

For this reason, until now, in this space, there has not been a social document approved by all the Orthodox Autocephalous Churches. At internal level, there is only one Church that has a social document, namely, the Russian Orthodox Church (2011). Its drafting started at the beginning of the 90 s and it was approved in 2000, being important, but still having some points that can be improved (Morariu 2015:39, 2020a:33-35; Preda 2010:167). Aspects such as bioethics or social ethics are included, but not enough emphasised. The Pan-Orthodox Council of Crete from 2016 was expected to release a social document. ${ }^{1}$ Unfortunately, despite some accents, which were well put on certain social issues (Morariu 2018:1; Nate \& Buda 2019:15), there is not even a chapter of the final document released by participants in the meeting, dedicated exclusively to social topics (Morariu 2020b:27); there are only references to the relationships of the Orthodox Church with the rest of the world or the opinion of the Church regarding science and its evolution. Noticing all these aspects, one can definitely say that there are still important steps to take in order for the Orthodox space to reach a social doctrine and a social teaching of the Church, which can be closer to the one of the Catholic or the Protestant ones. This constitutes another important weakness, which should be at least partially amended by a later document, such as 'For the Life of the World', which I am tackling in the present research.

1.See https://www.holycouncil.org/ 
Nonetheless, one must notice that there are important initiatives belonging to some of the theologians and heads of the local Churches from this area. Clearly, such an example is that of the Ecumenical Patriarch Bartholomew. Considered 'the Green Patriarch' (Morariu 2019:23), he is one of the important authors of theology who approached the topic of ecology (Bartholomée 2015; Bartholomew 2018:12-21; ed. Chryssavgis 2003; Chryssavgis 2012a, ed. 2012b) and has greatly influenced (Morariu 2020c:124) relevant leaders of related Churches, for instance, Pope Francis (Francis 2015). $\mathrm{He}$ is also the artisan of the latest document released by the Ecumenical Patriarchate of Constantinople, titled 'For the Life of the World'. ${ }^{2}$ Therefore, this document contains aspects of the ideas previously expressed by him in different circumstances. Moreover, it is expected that the experience that the Eastern Orthodox Church had in the Ecumenical field and the issues debated in assemblies such as the one from Graz, which took place in 1997 (Graziano 1998), or the one from Sibiu, which took place in 2007 (Leahy 2007:556-562), will be used in this sense and will provide relevant expertise in the field.

Having acknowledged the relevance of such a document both for the Eastern Orthodox area and for the Ecumenical space, I will try to emphasise its content and to speak about the elements of novelty that it brings in the Orthodox discourse. Whenever possible, I will also compare it with other important documents from different spaces.

\section{The social doctrine of the Eastern Orthodox Church reflected in the document 'For the Life of the World' General aspects}

Accepted by the Holy Synod of the Eastern Orthodox Church and welcomed by others from the Orthodox space, the document speaks seriously about topics, which are related to social life for the first time over the past few years. The 82 paragraphs, organised around 33 keywords, are segmented in seven big sections, are accompanied by an introduction and some rich conclusions and deal with topics such as the role of the Orthodox Church in the public space, human life and poverty, civil justice, peace and war, ecumenical relations and human rights or the relationships between theology and science. As it can be easily seen, the topics approached are current and related to social life, geopolitics, the life of the church, the common good, peace and war or social discrepancies. As in the case of previous attempts, it clearly has its minuses as well and, whilst issues such as bioethics are almost missing, those related to ecumenical realities and their potential outcomes are only artificially touched upon.

\section{Man and creation}

After offering a clear and well-argued anthropological basis of the document, in a way that makes it similar to the document Cultivate and care of the World Council of Churches
$(2020)^{3}$ (the difference residing in the fact that, in the Orthodox document, there are references not only to the Scripture but also to important voices of the first centuries of the Church, who are part of the tradition and therefore normative), the authors speak about man's responsibility in the confrontations of creation and about his duty to change the world inwardly and outwardly, ${ }^{4}$ offering a similar approach to Pope Francis' 'ecology of daily life' (Francis 2015:14). Calling to the rediscovery of the Church of the first centuries ${ }^{5}$, a topic that starts with a speech made by Father Georges Florovsky (Florovski 2009; Gavrilyuk 2014; Toroczkai 2008) at the beginning of the 20th century has become very commonly used in the Orthodox space and especially over the last few years, they then offer interesting examples from the biblical text as arguments.

The discourse later shifts towards the ecumenical field. There, the bishops of the Greek Patriarchate speak about the people who are not Christian and recognise the fact that 'all people possess some knowledge of good and all are able to some degree to perceive the requirements of justice and mercy'. For this reason, they see the need of Christian presence as a testimony based on topics such as justice and mercy. They also offer the example of Mary, Mother of God, in an attempt to help understand the Christian work as a form of synergy (para. 7):

[T]his means that Christians are permitted, and in fact obliged, to act as a prophetic presence in the world, speaking not only to the closed company of the baptized but to the whole of creation, recalling human beings everywhere to the decrees written into their very nature, and summoning them to the sanctifying labor of justice and mercy. And we take the Mother of God as our great exemplar here, for it is she, in her freely given assent to become the place of the advent of divine love in person - in her cooperation (synergeia) with God - who has bequeathed to us the purest model of true obedience to God's law: a willingness to give ourselves entirely to the presence of God's Son, to become the shelter and tabernacle of his indwelling in this world, to receive God's Logos as at once the highest vocation and the greatest fulfilment of our nature. (n.p.)

Despite the interesting highlights offered by this paragraph, one must also notice that the authors avoid to bring into attention sensitive topics such as the way in which the Orthodox should see the other Christians and interact with them or how they should act when confronting people who are not even Christians and with whom they are forced to come in contact because of daily realities. Perhaps a future

\footnotetext{
3. Here, the influences of the Ecumenical Patriarch Bartholomew are also visible. For example, in the beginning the following is asserted: Addressing human behaviour example, in the beginning, the following is asserted: Addressing human behaviour that is responsible for climate devastation constitutes not 'merely one justice issue
to be set alongside other justice concerns', but rather one 'of foundational importance for all existence and identity', as the Faith and Order Commission's theological reflection on the churches' pilgrimage of justice and peace states (World Council of Churches 2020:5). These ideas have often been used by the aforementioned leader of the Eastern Orthodox Church in different discourses.

4.'The work of transfiguring the cosmos is also a struggle against everything distorted and malignant, both in ourselves and in the damaged structure and fabric of a suffering creation and this means that, inevitably, this work must be an ascetical labour. To a very great degree, we are called to strive against the obstinate selfishness of our own sinful inclinations and to undertake a constant effort to cultivate in ourselves the eye of charity, which alone is able to see the face of Chris in the face of our every brother and sister, "the least of these," whom we meet as although each of them were Christ himself'. (para. 5: viewed 06 January 2021, from https://www.goarch.org/social-ethos)
} 
document will also deal with these aspects and will make up for the drawbacks of the present one, which are unfortunately related to stringent problems.

According to the same document, peace must be a purpose that should determine all those who believe in Christ to unite their forces in order to achieve it. The idea is presented in the first section and is raised again in the next sections. Human life and the way in which its conditions changed over the last few years also represent a concern of the authors of the document. They insist on the fact that the life of contemporary children is often threatened by technology and the consumption of electronic media. Quoting the Ecumenical Patriarch Bartholomew, who referred to this topic before (ed. Chryssavgis 2003:13), they underline the fact that 'A child's soul is altered by the influential consumption of electronic media, especially television and the internet and by the radical transformation' ${ }^{6}$

\section{Church and sexuality}

The problem of sexuality was and continues to be important for the Church. Nowadays, because of changes in society, it has become even more important. The Church is called to offer solutions or opinions regarding certain aspects of this complex topic. In this context, as expected, the document 'For the Life of the World' of the Ecumenical Patriarchate also refers to sexuality. In the end, as it can be seen in the 20th paragraph of the document, the institution maintains quite a conservative approach and, like in other situations, it seems to apply a tactic, which may not be very fruitful. Therefore, when aspects such as the use of contraceptives are not avoided, the terms used are abstract and general, without actually deepening topic. Compared with the Catholic area, where in matters of doctrine, for example, the formula both and can be used and here, the form or is used. The document uses the latter, without altering it. The authors insist on the fact that a good Christian must choose in matters of sexuality between marriage or monasticism. Tertium non datur! But, in the previous paragraph, there are some aspects that deserve to be presented, because of the fact that they contain some changes in accent (para. 19):

$[W]$ e live in an age in which sexuality has come more and more to be understood as a personal fate, and even a private matter. A great many political and social debates in the modern world turn upon the distinct demands and needs of heterosexual, homosexual, bisexual, and other sexual 'identities'. It is true, as a simple physiological and pathological fact, that the nature of individual sexual longing is not simply a consequence of private choice regarding such matters; many of the inclinations and longings of the flesh and the heart to a great extent come into the world with us, and are nourished or thwarted - accepted or obstructed - in us at an early age. It must be accounted, moreover, a basic right of any person - which no state or civil authority may presume to violate - to remain free from persecution or legal disadvantage as a result of his or her sexual orientation. But the Church understands human identity as residing primarily not in one's sexuality or in any other private quality, but rather in the image and likeness of God present in all of us. All Christians are called always to seek the image and likeness of God in each other, and to resist all forms of discrimination against their neighbors, regardless of sexual orientation. Christians are called to lives of sexual continence, both inside and outside of marriage, precisely on account of the sanctity of sexual life in the created order. But Christians are never called to hatred or disdain for anyone. (n.p.)

Of course, the conclusion is gentile and the final accent falls on the fact that the main aspect of life is not sexuality, but the salvation of the soul, which means that this paragraph, like others, does not practically offer a real solution to an important problem. It does offer a strong motivation to overcome all obstacles related to sexuality. However, at the same time, one must notice that, probably for the first time in history, the bishops of the Eastern Greek Orthodox Church insist on the fact that nobody should be persecuted for his or her sexual convictions, thus offering a clear and adequate answer both to other Christian traditions and to their own ultra-conservative faithful. In other words, they show that the answer of the Church to such a problem can be no other than love and prayer for the ones who are different and that their representative must pray for them and for their return to one of the two accepted ways. Another element of novelty is the fact that the authors of the investigated document consider relevant to mention that the nature of individual sexual longing is not simply the consequence of a choice in such matters. 'Temptations' and other aspects can contribute to a certain orientation of a person. However, at the same time, this aspect could be further studied and an analysis that brings together the spiritual fathers, the church fathers and the new discoverer of science should be welcomed. Like this, the Eastern Orthodox Church would indeed show that it is really interested in a dialogue with science and that it wants to find solutions to the common problems, which have appeared over time and to offer a valid answer to some of the burning challenges of society.

The passage must also be read in connection to the 17th one, where the authors speak about the way in which media consumption can influence people and especially the youth and can determinate their choices ${ }^{7}$ and with the 21st one, which speaks about the marriage between an Orthodox and someone with a different Christian background, offering a broader perspective on the topic and showing that the Church, which released such a document, is indeed capable of a dialogue with society and the ecumenical area, although there are still many steps to take.

\section{Orthodoxy and human rights}

The way in which orthodoxy understands human rights is part of the seventh section, which contains the paragraphs from 61 to 67 . Here, the bishops insist on the fact that human rights must be understood in the context of man's creation by God in His image and likeness. Although it also has its

7.As His All-Holiness Ecumenical Patriarch Bartholomew stated in his 2016 Proclamation of Christmas: 'A child's soul is altered by the influential consumption of electronic media, especially television and the internet, and by the radical of electronic media, especially television and the internet, and by the radical
transformation of communication'. (para. 17: viewed 06 January 2021, from https:// www.goarch.org/social-ethos). 
minuses related to certain aspects, it must be said that this is one of the most complex chapters of the document. The 64th paragraph speaks about the relevance of protecting the principle of religious freedom, both in the public and in the private sphere. They see religious freedom as being (para. 67):

$[T]$ he freedom of conscience, belief, and religion, including, alone and in community, in private and in public, the right to freedom of worship and practice, the right to manifest one's religion, as well as the right of religious communities to religious education and to the full function and exercise of their religious duties, without any form of direct or indirect interference by the state. (n.p.)

Based on this freedom, the Greek bishops will disapprove any form of violence, harassment or bullying, as it is clearly stipulated in the 48th paragraph ${ }^{8}$ and as it was also mentioned in the documents released by the Crete Pan-Orthodox Council from 2016. In addition, despite attempts to be politically correct and to keep a certain distance in formulations and opinions, they do offer the perspective of the institution, which they are called to represent in this aspect (para. 49):

[F]or Orthodox Christians, the way of peace, of dialogue and diplomacy, of forgiveness and reconciliation is always preferable to the use of violence, capital punishment, or police or military force. The highest expression of Christian holiness in response to violence is perhaps found in those who strive every day to create understanding and respect among persons, to prevent conflict, to reunite those who are divided, to seek to create economic and social mechanisms for alleviating the problems that often lead to violence, and to welcome and care for those who are marginalized and suffering. It is found among those who dedicate themselves to extirpating the spiritual roots of violence in themselves and others. (n.p.)

Like in the Catholic space (the Pontifical Council for the Justice and Peace 2004:72), the Orthodox bishops know that, as they do not have a divine basis, human rights are perfectible and, for this reason, they are willing to have a dialogue with the states and to put their experience in the service of the common good, in order to overcome violence, crimes and other problems.

As a special note, I must mention that, from the entire document, which is indeed a complex and revolutionary one, especially for the Orthodox world, being more complex than the Russian one (Morariu 2020a:34), this section is the most complex one, containing the deepest analyses and references, which have practical relevance.

\footnotetext{
8. The Orthodox Church cannot, naturally, approve of violence, either as an end in
itself or even as a means for achieving some other end, whether this is in the form itself or even as a means for achieving some other end, whether this is in the form
of physical violence, sexual abuse or the abuse of authority. In every celebration of the Eucharist, the Church prays in her Great Litany "for the peace of the whole world, let us pray to the Lord." Peace, for the Church, is more than a state of armistice lightly imposed upon a naturally violent world. It is, rather, a real revelation of the still deeper reality of creation as God intends it and as God fashioned it in his eternal counsels. It is the restoration of creation to its true form, if only in part. True peace is the very presence of God amongst us. A great many saints of the Church, such as St. Moses the Ethiopian and St. Seraphim of Sarov, have freely chosen to sucf as St. Moses the Ethiopian and St. Seraphim of Sarov, have freely chosen to suffer violence without reciprocating it or seeking redress. According to sacred tradition, the saintly Kievan princes Boris and Gleb offered up both their kingdoms and their lives rather than lifting their hands in violence against others to defend themselves or their possessions. The Church honours all such martyrs for peace as witnesses to the power of love, to the goodness of creation in its first and final form and to the ideal of human conduct established by Christ during his earthly ministry'. (para. 48: viewed 06 January 2021, from https://www.goarch.org/social-ethos; cf. Morariu 2018:2).
}

\section{The Orthodox Church and the contemporary world}

The last section (paragraphs 68-78) contains references to science, technology and the way in which they can influence human life. It can somehow be seen as a continuation of the previous section. As a recent document of the World Council of Churches (2020) mentions:

[E]cological efforts often confront national, economic, and political interests. National and regional government decisions about climate justice are often shaped by the economic development interests of each nation or region. (p. 6)

The authors of the document speak about ecology and the necessity of taking care of our common house. Nonetheless, beyond the measures that are meant to protect the resources, which are not renewable and to stop the destruction of the planet, the Orthodox bishops from the Greek Ecumenical Patriarchate of Constantinople insist on a fact that has been previously emphasised by Pope Francis in Laudato Si (Francis 2015:12; acc. Mshana 2013:7). The ecology of daily life, which is the key aspect mentioned, is more present in this section than in the other ones, with the accent being put on the fact that the responsibility of the Christian is that of transforming the fallen nature. References to Pope Francis are not missing.

Going back to the beginning of the document, the reader can see an interesting approach, which also refers to the relationship between the Church and society. The following is said (para. 13):

[O]urs is, it is often said, a secular age. This is not to say, of course, that religion has faded from all societies. In some of them, in fact, it remains as potent a cultural force as it ever was. And, even in the most thoroughly laicized and secularized nations of the West, religious belief and practice remain far livelier than one would expect if the religious impulse were merely an accidental aspect of human culture. But the constitutions of most modern states, even those that formally recognize an established church, assume the civic priority of a public space devoid of religious associations, and of a political order free from ecclesiastical authority. Many today, in fact, believe that democratic society is possible only to the degree that religion has been relegated to the private sphere entirely, and allowed no role in the articulation of policy. (n.p.)

The things asserted that these are in fact developed in the second part of the document, because, starting from the fact that, although some societies are secularised, religion is an important element of man's cultural and civil life, the Church can now dialogue with society and it is called to establish a relationship with it. In societies where religion would be excluded, it would not be possible to have any form of dialogue with the world.

As expected, the conclusions of the document titled 'For the Life of the World' (2020) (paragraphs 79-82) have an optimistic tone and contain an honest self-evaluation of the content and its limits made by the authors. Being aware of the limits of the document, the bishops insist on the fact that there are other aspects that could be deepened (still, without 
mentioning any of them, which would definitely not be extremely difficult), whilst some of the issues presented can constitute the topic of a larger discussion (paragraph 79). The connection made by the authors between ethical and liturgical prescripts is also important. A relevant emphasis is also made in paragraph 82 , which states that:

[T]he Orthodox Church sees it as her calling to condemn cruelty and injustice, the economic and political structures that abet and preserve poverty and inequality, the ideological forces that encourage hatred and bigotry; but it is not her calling to condemn the world, or nations, or souls. Her mission is to manifest the saving love of God given in Jesus Christ to all creation: a love broken and seemingly defeated upon the cross, but shining out in triumph from the empty tomb at Pascha; a love that imparts eternal life to a world darkened and disfigured by sin and death; a love often rejected, and yet longed for unceasingly, in every heart. It speaks to all persons and every society, calling them to the sacred work of transfiguring the world in the light of God's Kingdom of love and eternal peace. (n.p.)

The term 'condemn' looks rather harsh for the Orthodox space and for some bishops. However, in this context, it seems the adequate one, if we take into account the fact that, like never before in history, injustice and in all its forms, cruelty and numerous other negative issues, many of them related to the political area have increased and there is need of a common attitude, clear and articulated, regarding these problems. Clearly, it would be wonderful if the Eastern Orthodox Church would team up with other Churches and Christian organisations in order to have more visibility and to put pressure, when necessary, on the institutions that could stop such manifestations. The end of the paragraph is also interesting. In full accordance with the text of the Bible, it claims that the real force that would change the world at a profound level is love, which is why it must be cultivated in all the structures and must be transformed in the mechanism, which moves the relationships between people.

\section{Conclusion}

Unfortunately, because of space limits, a deeper analysis of some of the aspects found in the document I have presented is not possible. Nonetheless, as a conclusion, I must say that it is an important step in the development and implementation of the social doctrine of the Orthodox Church and of its social teaching. It speaks not only about topics that have been previously approached but have not been developed enough so far, such as human rights, violence, poverty and social inequalities but also sexuality and others, which have been discussed and still represent a problem. Despite its incompleteness, acknowledged by the authors in the end, it puts new accents and shows the openness of the Eastern Orthodox Church of Constantinople and of its head, the Ecumenical Patriarch Bartholomew, to dialogue. At the same time, it offers some solutions to contemporary crises or, when this is not possible, it shows the causes of some of these woes. Having unequal sections and topics approached from various nonsymmetrical points of view, it does put on the table topical aspects, more than previous meetings, such as the Pan-Orthodox Council of Crete or the Russian Social document from 2000. Consequently, it will definitely constitute a topic of dialogue amongst the Eastern Orthodox Churches all around the world and it will also probably be important in the context of ecumenical dialogue. However, as I have already said, there is still place for improvement as far as the document is concerned and the Eastern Orthodox Church can learn from both the Ecumenical experience and that of other Churches in matters of social doctrine.

Sadly, the COVID-19 pandemic that struck us shortly after its release determined the reorientation of the theological and social discourse towards other priorities, which degraded the dissemination of the ideas contained in the document to a second position. I hope that, after this crisis ends, it will be brought back in the frontline of debate and, after it is sanctioned by all the other Orthodox Churches, it will eventually be a social document, which defines orthodoxy and its actions in the public sphere and in the ecumenical dialogue.

\section{Acknowledgements Competing interests}

The author declares that he has no financial or personal relationships that may have inappropriately influenced him in writing this article.

\section{Author's contributions}

I.M.M. is the sole author of this research article.

\section{Ethical considerations}

This article followed all ethical standards for research without direct contact with human or animal subjects.

\section{Funding information}

This research received no specific grant from any funding agency in the public, commercial or not-for-profit sectors.

\section{Data availability}

Data sharing is not applicable to this article as no new data were created or analysed in this study.

\section{Disclaimer}

The views and opinions expressed in this article are those of the author and do not necessarily reflect the official policy or position of any affiliated agency of the author.

\section{References}

Bartholomée, P., 2015, Et DieuVit que CelaEtait Bon. La Vision Théologique de la Créationdans la Tradition Orthodoxe, Les Editions du Cerf, Paris.

Bartholomew, E.P., 2018, 'Ecclesiology as ecology: Orthodox insights', Concilium 5(5), 12-21.

Chryssavgis, J. (ed.), 2003, Cosmic grace - Humble prayer. The ecological vision of the Green Patriarch Bartholomew, William B. Eerdmans, Grand Rapids, MI.

Chryssavgis, J., 2012a, 'Introduction', in J. Chryssavgis (ed.), On Earth as in heaven: Ecological vision and initiatives of Ecumenical Patriarch Bartholomew, pp. 1-22, Fordham University Press, New York, NY. 
Chryssavgis, J. (ed.), 2012b, On Earth as in heaven: Ecological vision and initiatives of Ecumenical Patriarch Bartholomew, Fordham University Press, New York, NY.

Florovski, G., 2009, Sensul Ascezeicreștine [The sense of the Christian askesis], Patmos Press, Cluj-Napoca.

Francis, P., 2015, Encyclical letter Laudato Si' of the Holy Father Francis on care for our common home, Casa Editrice Vaticana, Vatican.

Gavrilyuk, P.L., 2014, George Florovskyș irenașterea religioasărusă [George Florovsky and the Russian religious renaissance], Doxologia Publishing House, lasi.

Graziano, L., 1998, Riconciliazione: Dono di Dio, sorgente di vita nuova : CCEE-KEKatti ufficiali dell'Assemblea ecumenica europea di Graz, 23-29 giugno 1997, Pazzini Press, Rimini.

Ică, I. Jr. \& Marani, G., 2002, Gândireasocială a Biserici. Fundamente, documente, analize, perspective [The social teaching of the church. Fundements, documents, analyzes, perspectives], Deisis Press, Sibiu.

Leahy, B., 2007, 'Therapy of renewal: The Third European Ecumenical Assembly', The Furrow 58(10), 556-562.

Morariu, I.-M., 2015, 'Fundamentele Conceptiei Sociale a Bisericii Ortodoxe Ruse Reflectateîn Documentul Sinodal din Anul 2000 [The bases of the social conception of the Russian Orthodox Church as reflected in the Sinodal document from 2000]', Tabor 9(4), 37-41.

Morariu, I.-M., 2018, 'Eastern orthodox churches and Ecumenism according to the Holy Pan-Orthodox Council of Crete (2016)', HTS Teologiese Studies/Theological Studies 74(4). a4954. https://doi.org/10.4102/hts.v74i4.4954

Morariu, I.-M., 2019, 'Sociological relevance of the ecological thought of Ecumenical Patriarch Bartholomew', European Journal of Science and Theology 15(5), 19-25.

Morariu, I.-M., 2020a, 'Russian Orthodox Church, Fondamenti della dottrina sociale, Edizioni Studio Domenicano, Bologna, 2011, 198 pp', Oikonomia - Rivista di Etica e Scienze Sociale 19(2), 33-35.
Morariu, I.-M., 2020b, 'Il Sinodo Pan-ortodosso di Creta (2016) e la dottrina sociale della Chiesa Ortodossa', Oikonomia - Rivista di Etica e ScienzeSociale 19(1), 27-28.

Morariu, I.-M., 2020c, 'Ecology - Main concern for the Christian space of the 21st century? Catholic and orthodox perspectives', Journal for the Study of Religions and Ideologies 19(56), 124-135.

Mshana, R., 2013, 'Preface', in R.R. Mshana \& A. Peralta (eds.), Economy of life: Linking poverty, wealth and ecology, pp. 5-7, World Council of Churches Publications, Geneva.

Nate, S. \& Buda, D., 2019, 'Eastern European geopolitics and ecclesial autocephaly for the Ukrainian orthodox church: A hard way for Ukraine', Teologia 80(3), 11-38.

Pontifical Council for the Justice and Peace, 2004, Compendiodella Dottrina Sociale della Chiesa, Libreria Editrice Vaticana, Vatican.

Preda, R., 2010, Ortodoxia \& ortodoxiile: Studii social-teologice [Orthodoxy and Orthodoxies - Social-Theological Studies], Eikon Publishing House, Cluj-Napoca.

Russian Orthodox Church, 2011, Fondamentidella Dottrina Sociale, Edizioni Studio Domenicano, Milano.

Toroczkai, C.I., 2008, Tradiţia patristică În modernitate: eclesiologia părintelui George Florovski (1893-1979) [The patristic tradition in modernity - Father Georges V. Florovsky's ecclesiology (1893-1979)], Andreiana Press, Sibiu, viewed 06 J. Florovsky's ecclesiology (1893-1979)], Andreiana Press, Sibiu, viewed 06
January 2021, from https://www.goarch.org/social-ethos, viewed 10 February 2021, from https://www.holycouncil.org/.

World Council of Churches, 2019, Come and see: A theological invitation to the pilgrimage of justice and peace, Faith and order paper no. 224, World Council of Churches Publications, Geneva.

World Council of Churches, 2020, Cultivate and care - An ecumenical theology of justice for and within creation, Faith and order paper no. 226, World Council of Churches Publications, Geneva. 